and Scottish Railway Company; Sir Kenneth Lee, chairman, Tootal Broadhurst Lee Company, Limited; Miss Myra Curtis, principal, Newnham College, Cambridge; Mr. A. J. T. Day, chairman, staff side, National Whitley Council ; Mr. A. L. N. D. Houghton, staff side, National Whitley Council ; Sir Thomas Gardiner, director-general, General Post Office ; Sir Robert Wood, deputy secretary, Board of Education and Mr. H. Wilson Smith, under-secretary, Treasury. The terms of reference of the Committee are: "To examine the general question of the training of Civil servants, including the question whether a Staff College should be established, and if so, the particular form and character which that college should take".

\section{Earthquake in Mid-Atlantic}

The United States Coast and Geodetic Survey, in co-operation with Science Service and the Jesuit Seismological Association, has determined the provisional epicentre of the earthquake of December 31 which took place at about $12 \mathrm{~h} .03 \cdot 7 \mathrm{~m}$. U.T. The instrumental data on which the calculations were based were obtained from the observatories at St. Louis, Tucson, Sitka, San Juan, Burlington, Pasadena, Spring Hill, Lincoln, Huancayo and Fordham. The epicentre turned out to be in the vicinity of latitude $18 \cdot 1^{\circ} \mathrm{N}$., longitude $47.0^{\circ} \mathrm{W}$. This is in the region of the mid-north-Atlantic ridge between Puerto Rico (West Indies) and the Cape Verde Islands. Earthquakes are known to occur in this region from time to time and it would be interesting to have reports of the shock from ships which may have been in the region at the time.

\section{Comet Oterma (1942f)}

Dr. WhrPple has computed the following elements of this comet :

$\left.\begin{array}{rcc}T & 1942 & \multicolumn{2}{l}{\text { December } 18 \cdot 859} \\ \omega & 358^{\circ} & 03 \cdot 0^{\prime} \\ \Omega & 78 & 30 \cdot 8 \\ i & 17 & 57 \cdot 6 \\ a & 11.9604 \\ e & 0.86622 \\ P & 41.4 \text { years. }\end{array}\right\} 1942 \cdot 0$

Its positions for a few dates in April are given below. For intermediate dates it will be sufficiently accurate to interpolate, allowing a daily motion in R.A. $+2 \cdot 7 \mathrm{~m}$. during April 2-12 and $+2 \cdot 2 \mathrm{~m}$. during April 12-28. The corresponding figures in declination are $-0 \cdot 2^{\circ}$ and $-0 \cdot 1^{\circ}$. It is not an easy object to find as its magnitude in the middle of the month, assuming the $p^{2} r^{4}$ law, is about $13 \cdot 5$.

$\begin{array}{cllrrr}\text { Date } 1943 & & \text { R.A. } & \text { Dec. } & \rho & r \\ \text { April } 2 \cdot 0 \mathrm{~d} . & \text { 7h. } 02 \cdot 2 \mathrm{~m} . & +40 \cdot \theta^{\circ} & 1 \cdot 723 & 2 \cdot 038 \\ 12 & 7 & 29 \cdot 5 & 38 \cdot 9 & 1 \cdot 957 & 2 \cdot 121 \\ 28 & 8 & 05 \cdot 3 & 37 \cdot 1 & 2 \cdot 207 & \mathbf{2} \cdot 239\end{array}$

\section{Comet Whipple (1942g)}

ThIs comet is no longer a naked-eye object but can be seen with the aid of a small telescope. Positions are given for the early part of April.

\begin{tabular}{clcrrr} 
Date 1943 & \multicolumn{2}{c}{ R.A. } & Dec. & $\rho$ & \multicolumn{1}{c}{} \\
April 2.0d. & 12h. $42 \cdot 9 \mathrm{~m}$. & $+46 \cdot 5^{\circ}$ & $0 \cdot 729$ & $1 \cdot 565$ \\
6 & 12 & $44 \cdot 3$ & $44 \cdot 9$ & $\cdot 762$ & .594 \\
10 & 12 & $45 \cdot 6$ & $43 \cdot 3$ & $\cdot 796$ & $\cdot 624$
\end{tabular}

\section{The Night Sky in April}

New moon occurs on April 4d. 21h. 53m. U.T., and full moon on April 20d. $11 \mathrm{~h}$. $11 \mathrm{~m}$. Conjunctions with the moon are as follows : April 7 d. 11 h., Venus $6^{\circ}$ N. ;
April 9d. 01h., Saturn $3^{\circ}$ N. ; April 12d. 05h., Jupiter $3^{\circ}$ N. ; April $29 \mathrm{~d}$. 17h., Mars $0 \cdot 1^{\circ} \mathrm{S}$. Occultations of stars brighter than magnitude 6 are as follows : April 16d. 22h. 16m., $\chi$ Leo $(D)$; April 18d. 21h. 55.3 m., $\gamma$ Vir. $(D)$; April 18d. 22h. $43 \cdot 2 \mathrm{~m} ., \gamma$ Vir $(R)$; April 25 d. $03 \mathrm{~h} .42 \cdot 6 \mathrm{~m} ., 21 \mathrm{Sgr} .(R)$. The times are given for Greenwich and $D$ and $R$ refer to disappearance and reappearance respectively. Mercury is in superior conjunction on April 4, reaching its greatest eastern elongation on April 30 when it sets about 2lh. 25m., two hours after sunset. Venus, an evening star, is in conjunction with Saturn on April 25d. 04h., Venus $3 \cdot 1^{\circ} \mathrm{N}$. Mars souths at $8 \mathrm{~h} .34 \mathrm{~m}$. in the middle of the month, but is too low for favourable observation in Great Britain. Jupiter souths at $17 \mathrm{~h} .42 \mathrm{~m}$. in the middle of the month and is well placed for observation in the earlier portion of the night. Saturn sets about $23 \mathrm{~h}$. in the middle of the month and will soon be too close to the sun for favourable observation. Times of setting are given approximately for the latitude of Greenwich. The Lyrid shower of meteors, April 18-24, which has not been very strong in recent years, will not be easily observed owing to moonlight.

\section{Announcements}

Dr. Karl T. Compton, president of the Massachusetts Institute of Technology, will deliver the Pilgrim Trust Lecture before the Royal Society on May 6: he will speak on "The Organization of American Scientists for the War'.

The trustees of the Ray Lankester Fund have appointed Dr. Shu-Ping Chu, of Queen Mary College, University of London, as investigator for 1943-44 to carry out research at the Plymouth Laboratory of the Marine Biological Association into the effect on the development of marine algæ of the presence or absence of different substances in sea water.

The following appointments in the Colonial Service are announced : R. A. Hutchinson, to be veterinary officer, Gambia; A. R. J. McGregor and E. J. Westcott, to be veterinary officers, Nigeria; C. B. Garnett, senior agricultural officer, to be assistant director of agriculture, Nyasaland.

A CORRESPONDENT of The Times writing from Gibraltar states that tunnellers of the Royal Engineers working there have discovered a hitherto unknown cavern. It is said to be of extraordinary beauty, with white, grey and red stalactite columns, and contains a lake of fresh water nearly 40 yards long and $7 \mathrm{ft} .-20 \mathrm{ft}$. deep. The largest column is $7 \mathrm{ft}$. in diameter and $40 \mathrm{ft}$. high.

A USEFUL $16 \mathrm{pp}$. brochure on the preparation and preservation of insects for collections has been written by J. Manson Valentine of the U.S. Department of Agriculture and is published as No. 6, vol. 103 of the Smithsonian Miscellaneous Collections (November 1942). Although it has particular reference to the order Coleoptera it will be found applicable to some other orders of insects also. The methods of mounting, preserving, relaxing, labelling, etc., and other treatment of specimens are clearly described. Some of the technique explained will be found useful and more especially by British workers who are not always familiar with American methods. 